\title{
COMMENTS
}

\section{RECENT PROBLEMS UNDER SECTION 2(d) OF THE ROBINSON-PATMAN ACT}

As each year passes, commentaries on the vicissitudes, anomalies and practical problems of the Robinson-Patman Act continue to be written. This twenty-fifth anniversary year of the controversial amendment to the Clayton Act promises little limitation on such proliferation by scholars and practitioners. The impact of the 1959 Term's Broch case on the administration and substance of section 2(c) has been extensively assessed in the legal journals. 1 The language and scope of the Supreme Court's analysis of section 2(e) in the 1958 Term Simplicity Patterns decision has been equally searched and researched for answers to other ambiguities in the act. 2 The reason for such outpourings is plain enough: any federal statute so inartistically drafted and whose impact reaches into every aspect of the businessman's distributive and pricing process causes concern in the market place and delight in academia.

Only one subsection, however, remains to be directly construed by the Supreme Court3-the so-called "advertising allowance" section 2(d), which forbids payment by a seller for "services and facilities" furnished by a customer unless such payment is made available to all competing customers on "proportionally equal terms."4 Supreme Court dicta in cases concerning other

1 FTC v. Henry Broch \& Co., 363 U.S. 166 (1960) (Justices Whittaker, Frankfurter, Harlan, and Stewart, dissenting). The Broch case in the Seventh Circuit was noted in two law reviews, while the Supreme Court reversal has been examined in no less than eleven journals. See, e.g., 74 Harv. L. Rev. 169 (1960); 29 Geo. Wash. L. Rev. 178 (1960); 109 U. PA. L. REv. 630 (1961); 28 U. CHI. L. Rev. 505 (1961).

2 FTC v. Simplicity Pattern Co., 360 U.S. 55 (1959). Simplicity, like Broch, has not suffered from a dearth of reaction in the law reviews. See, e.g., 45 CORNELI L. Q. 349 (1960); 28 Geo. Wash. L. Rev. 671 (1960); 38 TeXas L. Rev. 631 (1960).

3 Technically, the Supreme Court has reviewed a section 2(d) case, but the matter at issue was whether or not a judicial order was appropriate with reference to parts of a Commission order that had not been violated in a contempt proceeding. Thus, no substantive question of interpretation was presented. FTC v. American Crayon Co., 350 U.S. 907 (1955); 352 U.S. 806 (1956).

4 Section 2(d) provides: "That it shall be unlawful for any person engaged in commerce to pay or contract for the payment of anything of value to or for the benefit of a customer of such person in the course of such commerce as compensation or in consideration for any services or facilities furnished by or through such customer in connection with the processing, handling, sale, or offering for sale of any products or commodities manufactured, sold, or offered for sale by such person, unless such payment or consideration is available on proportionally equal terms to all other customers competing in the distribution of such products or commodities." 38 Stat. 730 (1914), as amended, 49 Stat. 1526 (1936), 15 U.S.C. § 13(d) (1958). 
sections have, of course, been some aid, 5 but federal court decisions have been sparse until the last few years. ${ }^{6}$ The Federal Trade Commission's opinion in the 1953 Soap cases, 7 for example, and the Commission's Guides for Advertising Allowances and Other Merchandising Payments and Services, adopted May 19,1960 , are significant attempts at the administrative level to make the section workable for the businessman and his counselor. 8 Many problems, however, still remain to be resolved by the courts as the Commission intensifies its activity under the section.9 Furthermore, recent Commission opinions have been characterized by strong dissents. 10 An investigation of new developments and current issues, then, once again seems warranted.11

5 Corn Prods. Ref. Co. v. FTC, 324 U.S. 726 (1945) (section 2(e)); FTC v. Morton Salt Co., 334 U.S. 37, 55 (1948) (section 2(a)); Automatic Canteen Co. v. FTC, 346 U.S. 61, 73 (1953) (section 2(f)); FTC v. Simplicity Pattern Co., 360 U.S. 55, 65 (1959) (section 2(e)).

6 Atalanta Trading Corp. v. FTC, 258 F.2d 365 (2d Cir. 1958); State Wholesale Grocers v. Great Atl. \& Pac. Tea Co., 258 F.2d 831 (7th Cir. 1958) cert. denied sub nom. General Foods Corp. v. State Wholesale Grocers, 358 U.S. 947 (1959); P. Lorillard Co. v. FTC, 267 F.2d 439 (3d Cir.), cert. denied, 361 U.S. 923 (1959); Swanee Paper Corp. v. FTC, 291 F.2d 833 (2d Cir. 1961).

7 Lever Bros. Co., 50 F.T.C. 494 (1953).

8 The Guides of course are not technically binding on either the Commission or the courts, nor have they gone without criticism. See Shniderman, Collateral Discrimination under the Robinson-Patman Act-Section 2(c), (d) and (e), in 17 ABA ANTITRUST SECTION 410 (1960). Earlier, in 1954, the FTC had promulgated Trade Practice Rules for the Cosmetic Industry, largely to obviate some of the practical difficulties arising from Elizabeth Arden Sales Corp. v. Gus Blass Co., 150 F.2d 988 (8th Cir.), cert. denied, 326 U.S. 773 (1945). The Rules are set forth in 3 CCH TRADE REG. ReP. I 20221 (1954).

${ }^{9}$ From October 1, 1956, to August 1, 1960, 190 of the 319 Robinson-Patman complaints were issued under the provisions of 2(c) and 2(d). Rowe, Expectation Versus Accomplishment Under the Robinson-Patman Act, 1936-1960, in 17 ABA ANTITRUST SECTION 298, 311 n.52 (1960). An FTC Press Release, July 3, 1960, noted that 463 members of the food industry are being investigated for possible advertising and promotional allowance violations.

${ }^{10}$ See Liggett \& Myers Tobacco Co., No. 6642, FTC, September 9, 1959 (Kern, dissenting); Exquisite Form Brassiere, Inc., No. 6966, FTC, October 31, 1960 (Tait, dissenting); Grand Union Co., No. 6973, August 12, 1960 (Tait, dissenting).

${ }^{11}$ As suggested earlier, the literature on section 2(d) is voluminous. The most recent valuable commentaries can be found in Shniderman, supra note 8, at 411-21; EDWARDS, The Price Discrimination Law 153-207 (1959); Austin, Price Discrimination and Related Problems Under the Robinson-Patman Act 117-56 (rev. ed. 1959).

Other studies, articles, and comments arranged chronologically include: Comment, The Robinson-Patman Act in Action, 46 YALE L.J. 447, 465-72 (1937); Dunn, Sections 2(d) and (e), in CCH Rodinson-PATMAN ACt SYMPosium 55 (1946); FeldMAN \& ZoRN, AdVERTISING and Promotional Allowances (1948); Layton, Demonstrators on Proportionally Equal Terms, in CCH Robinson-Patman ACt Symposium 38 (1948); Comment, 52 Mich. L. Rev. 1198 (1954); ATt'y Gen. Nat'l Comm. ANTITRUST Rep. 189-93 (1955); Rowe, How to Comply with Sections 2(c)-( $(f)$, in CCH ANTITRUst LAW Symposium 124, 131-36 (1957); Fisher, Sections 2(D) and (E) of the Robinson-Patman Act: Babel Revisited, 11 VAND. L. REv. 453 (1958).

For reviews of the federal cases and FTC proceedings in 1959 and 1960, see Kintner, Resurgens: The Federal Trade Commission in 1959, in CCH ANTITRUsT LAw Symposium 30, 36-38 (1960); Kintner, The Federal Trade Commission in 1960-Apologia Pro Vita Nostra, in CCH ANTitrust Law Symposium 21, 31-33 (1961); Oppenheim, Developments in Antitrust During the Past Year, in 17 ABA Antitrust Section 33, 116-20 (1960). 
General considerations of section 2(d) will first be traced to present the background necessary for a closer examination of particular problems in the application of the section. Specific advertising and promotional arrangements in the food industry will then be discussed, especially the "Anniversary" and "Special" sales, brand names, and the "Chain Lightning" promotion initiated by the broadcasting and television industry. The recent Liggett \& Myers proceeding12 will be examined in order to throw a fuller light on the important "indirect customer" conundrum. Finally, the problem most likely to first reach the Supreme Court under section 2(d)-whether or not the meetingcompetition defense of section $2(\mathrm{~b})$ is available to the respondent in a 2(d) charge-will be analyzed.

\section{General Considerations}

Section 2(d) was enacted to prevent a prevalent form of indirect price discrimination, whereby large purchasers received special discounts and rebates purportedly for advertising and promotional services, which, however, were usually never furnished.13 Section 2(e) was later added to the original bill to supplement 2(d) so as to cover the seller's unjust furnishing of facilities and services as juxtaposed to paying for them. ${ }^{14}$ The practices most common at the time of the act's adoption were joint advertising and in-store promotion of the seller's goods by the customer. 15 Thus the section's main concern was with merchandising services rendered in connection with the resale of consumer goods. But the potential ambit of the sections' coverage was not delineated, as the oft-quoted remarks of Congressman Utterback, Chairman of the House conferees at the time of the act's passage, suggest:

The existing evil at which this part of the bill is aimed is, of course, the grant of discriminations under the guise of payments for advertising and promotional services which, whether or not the services are actually rendered as agreed, results in an advantage to the customer so favored as compared with others who have to bear the cost of such services themselves. The prohibitions of the bill, however, are made intentionally broader than this one sphere, in order to prevent evasion in resort to others by which the same purpose might be accomplished, and it prohibits payment

12 Liggett \& Myers Tobacco Co., No. 6642, FTC, September 9, 1959.

13 See S. REP. No. 1502, 74th Cong., 2d Sess. (1936; H.R. REP. No. 2287, 74th Cong., $2 d$ Sess. (1936).

14 EDwards, op. cit. supra note 11, at 51. The text of section 2(e) provides: "That it shall be unlawful for any person to discriminate in favor of one purchaser against another purchaser or purchasers of a commodity bought for resale, with or without processing, by contracting to furnish or furnishing, or by contributing to the furnishing of, any services or ficilities connected with the processing, handling, sale, or offering for sale of such commodity so purchased upon terms not accorded to all purchasers on proportionally equal terms." 49 Stat. 1526 (1936), 15 U.S.C. §13(e) (1958).

is Şee S. Doc. No. 89, 73d Cong., 2d.Sess. (1934). 
for such services or facilities, whether furnished "in connection with the processing, handling, sale, or offering for sale" of the products concerned.16

The varieties of promotional and merchandising arrangements to which section 2(d) may apply are manifold. Any kind of advertising, handbills, window and floor displays, "push money" paid to clerks and salesmen of the customers, demonstrators, and giveaways are only a sample of day-to-day practices covered by the section. 17 In its narrowest form, the allowance might be paid for a specific advertisement placed in a particular media. In its broadest form, the allowance may be for co-operation between buyer and seller closely related to a functional discount.18 Because of this potential overlap with other sections of the act, a comparison will be of some value in indicating the general development and coverage of 2(d).

Section 2(a) prohibits direct and indirect discrimination in price that may result in injury to competition or competitors, with certain affirmative defenses permitted by the provisos.19 Section 2(d), on the other hand, is given an automatic character similar to sections 2(c) and 2(e), unless the seller can prove the requisite proportionality. Failure to comply thus means illegality per se, as under prevailing interpretations the Commission need not prove injurious effects on competition, 20 nor may the seller resort to cost justification. 21 Motive and lawful intent are equally irrelevant under 2(d), despite the weight the FTC usually gives such factors.22 Although the meeting-competi-

1680 CoNG. REC. 9418 (1936). (Emphasis added.)

17 See FTC Guides for Advertising Allowances and Other Merchandising Payments and Services 3 (May 19, 1960); FELDMAN \& ZORN, op. cit. supra note 11, at 88; EDWARDs, op. cit. supra note 11, at 174-75.

$18 \mathrm{See}$, for example, the Commission cases against American Crayon Co. and Binney \& Smith $\mathrm{Co}$., where school suppliers used advertising allowances to set up a special functional class of distributors. American Crayon Co., 32 F.T.C. 306 (1940); Binney \& Smith Co., 32 F.T.C. 315 (1940). The Commission unsuccessfully challenged, as merchandising allowances under 2(d), General Foods' discount of ten per cent to special distributors for wagon delivery of institutional grocery products. Instead, a violation of 2(a) was found. General Foods Corp., S2 F.T.C. 798 (1956). Accord, Yakima Fruit \& Cold Storage Co., No. 7718, FTC, October 10, 1960.

1949 Stat. 1526 (1936), 15 U.S.C. §§ 13(a)-(b) (1958),

${ }^{20}$ State Wholesale Grocers v. Great Atl. \& Pac. Tea Co., 258 F.2d 831, 839 (7th Cir. 1958); FTC v. Simplicity Pattern Co., 360 U.S. 55, 65 (1959) (dictum). Injury is of course relevant in private suits to establish damages. See National Nut Co. v. Kelling Nut Co., 61 F. Supp. 76, 83 (N.D. Ill. 1945). In one case, cost savings to the manufacturer were reflected in the service of a chain buyer distributing price lists. Chicago Seating Co. v. S. Karpen \& Bros., 177 F.2d 863 (7th Cir. 1949).

21 Cf. Oliver Bros., Inc. v. FTC, 102 F.2d 763, 767 (4th Cir. 1939).

22 "It is apparent that Congress has not made relevant the motive or intent of him who ... pays or contracts to pay." State Wholesale Grocers v. Great Atl. \& Pac. Tea Co., 258 F.2d 831, 837 (7th Cir. 1958). "This section of the Act does not concern itself with motive or intention. It is only concerned with the consequences which flow from an act. ... The Commission ... went farther than required ...." P. Lorillard Co. v. FTC, 267 F.2d 439, 444 C3d 
tion defense has been allowed in $2(\mathrm{e})$ proceedings, it is not yet available under 2(d).23

Because marketing allowances and services can be regarded as indirect discriminations in price, section 2(a) can be said to be applicable to any 2(d) situation. In two cases the Commission proceeded against buyers who had received payments for advertising, on the theory that such payments were a subterfuge for illegal discounts that impaired competition in ways forbidden by 2(a). 24 Equally anomalous to the conceptual structure of the act is the forced choice of sections as the seller-customer co-operation approaches a functional discount. ${ }^{25}$ If the service of the customer is recognized by the seller through specific payments for promotional activity, 2(d) applies. If the seller recognizes the usefulness of a customer's merchandising through a discount without policing and designating the services, its legality is judged by the different and more flexible standards of $2(a) .26$

The theory of the brokerage provision, section $2(c), 27$ envisages buyer and seller dealing at arms-length with only the intermediary broker justifiably paid for bringing the two together. Both sections 2(d) and 2(e), however, are premised on the belief that buyer and seller can furnish important facilities and services for each other. While the brokerage section in theory applies to the first sale of goods and 2(d) to their resale, the Carpel case revealed that there may be situations where a lump-sum payment encompasses both types of transactions. ${ }^{28}$ In this case, District Grocery Stores (D.G.S.), an organization of 275 retail grocers, was paid $\$ 5,000$ yearly to promote Carpel's frosted food line, with D.G.S. passing on to its retail members a credit of two per cent on all purchases of Carpel products. The Commission found that Carpel and D.G.S.

Cir. 1959). (Emphasis added.) But see Lever Bros. Co., 50 F.T.C. 494, 512 (1953), where the Commission stated, "[The plan] must be honest in its purpose and fair and reasonable in its application," quoted with apparent approval in FTC v. Simplicity Pattern Co., 360 U.S. 55, 61 n.4 (1959). A plan might be beyond reproach in its purpose but still violative of the section.

23 Henry Rosenfeld, Inc., 52 F.T.C. 1535 (1956). The problem is discussed in Part V infra.

24 Miami Wholesale Drug Co., 28 F.T.C. 485 (1939); Atlantic City Wholesale Drug Co., 38 F.T.C. 631 (1944). The charges were brought under section 2(f), 49 Stat. 1526 (1936), 15 U.S.C. § 13(f) (1958), which makes it unlawful for the buyer to "knowingly" induce or receive a prohibited discrimination in price.

25 See cases and discussion in note 18 supra.

26 See generally EDWARDS, op. cit. supra note 11, at 155, 175-76; Fischer, supra note 11, at 457-66; Rowe, supra note 11. In Champion Spark Plug Co., 50 F.T.C. 30 (1953), the 2(d) ch.arge was found to be covered in the 2(a) count, for the discounts given by the manufacturer for special sales services were discounts on the invoices off the billing listing, hence found to be merely a flat reduction in price.

2749 Stat. 1526 (1936), 15 U.S.C. § 13(c) (1958).

28 Carpel Frosted Foods, Inc., 48 F.T.C. 581 (1951), discussed in EDwards, op. cit. supra note 11 , at $179-80$. 
had both violated the brokerage section and Carpel had violated the advertising-allowance provision in making payments to D.G.S. not proportionally available to others. A portion of the $\$ 5,000$ was held to be in payment for inducing members to handle Carpel products, activities equivalent to the functions of a broker, while the balance was found to be for advertising and promotional services.

Since sections 2(d) and 2(e) deal in large part with similar transactions, they are generally considered companion sections. 29 Both embody the "proportionally equal terms" standard to payments by the seller in the former and services furnished by the seller in the latter. There are, however, discrepancies between the two sections in the language used. "Engaged in commerce" and "in the course of such commerce" have been read into section 2(e) to save its constitutionality. 30 The limitation in 2(a) to goods of "like grade and quality" has also been applied to 2(d) and (e). ${ }^{31}$ Section 2(d) uses the term "customers competing," while section 2(e) only uses the word "purchasers." Since the terms were used interchangeably throughout the legislative history, 32 they are generally regarded by the FTC as meaning the same thing. ${ }^{33}$

Who is a "purchaser" or "customer" under 2(d) and (e), however, is of considerable practical importance, for a favorable determination of this issue will exempt a respondent from these sections. For example, the Student Books decision ruled out the application of section 2(e) to consignees. ${ }^{34}$ Since "customers" may arguably be a broader term than "purchasers," commissions to consignees theoretically might be covered. 35 The General Foods ruling by the FTC refused to apply section 2(d) where the payments were not made in connection with the "resale of goods bought by [the customer]." 36 Thus, consign-

29 See Elizabeth Arden Sales Corp. v. Gus Blass Co., 150 F.2d 988, 990 (8th Cir.), cert. denied, 326 U.S. 773 (1945); AUSTIN, op. cit. supra note 11, at 120, 123.

30 The omission was held "inadvertent." Elizabeth Arden Sales Corp. v. Gus Blass Co., supra note 29. Elizabeth Arden, Inc. v. FTC, 156 F.2d 132 (2d Cir. 1946), cert. denied, 331 U.S. 806 (1947).

31 Atalanta Trading Corp. v. FTC, 258 F.2d 365 (2d Cir. 1958); Golf Ball Mfg. Ass'n, 26 F.T.C. 824 (1938).

32 See FELDMAN \& ZORN, op. cit. supra note 11, at 119.

33 Guide 12. See Elizabeth Arden, Inc. v. FTC, 156 F.2d 132 (2d Cir. 1946).

For further discussion of the discrepancy between the sections, see EDWARDs, op. cit. supra note 11, at 153 n.1; AusTIN, op. cit. supra note 11, at 124-25, 137-42.

34 Student Book Co. v. Washington Law Book Co., 232 F.2d 49 (D.C. Cir. 1955), cert. denied, 350 U.S. 988 (1956).

35 See the illuminating discussion in Rowe, Discriminatory Sales of Commodities in Commerce: Jurisdictional Criteria under the Robinson-Patman Act, 67 YALE L.J. 1155, 1157-58 (1958).

36 General Foods Corp., 52 F.T.C. 798, 828 (1956). State Wholesale Grocers v. Great Atl. \& Pac. Tea Co., 258 F.2d 831 (7th Cir. 1958), however, is probably contrary, for there payments made to A \& P's wholly owned magazine, Woman's Day, were held to be within the ambit of 2(d), even though some suppliers did not sell their grocery products in A \& $\mathbf{P}$ stores. See Note, 72 HaRv. L. REv. 1389 (1959). 
ment arrangements, already prevalent in the gasoline and publishing industries, appear to be increasing in popularity in other areas as well. Private litigation in Ludwig v. American Greetings Corp. ${ }^{37}$ has resulted in immunization of that practice for a manufacturer of greeting cards and paper supplies. ${ }^{38}$

Commission charges and treble damage suits under both sections have struck at a variety of commercial accommodations seemingly beyond typical promotional arrangements. Such complaints have included allowances for runway deliveries of cans, 39 furnishing of price lists, ${ }^{40}$ sales return privileges, ${ }^{41}$ payroll deductions, ${ }^{42}$ warehousing discounts, ${ }^{43}$ special packaging, ${ }^{44}$ and coupon books. 45 The outer limits of sections 2(d) and 2(e) are thus still to be defined.

When the businessman intends to enter into a promotional and advertising arrangement with his customers, practical problems proliferate. As mentioned earlier, however, the Guides and Commission opinions do present some standards that may be followed. The meaning of the "proportionally equal terms" phrase is an initial determination. 46 The safest course to follow is to base the payments made on the dollar volume or on the quantity of goods purchased curing a specified time. ${ }^{47}$ The Supreme Court in Simplicity Pattern noted with approval the relatively flexible and broad scope the FTC had accorded the srandard. 48 Thus, the section does not prohibit a seller from paying different amounts for services of various types. For example, the Commission upheld a gradated discount per case of soap depending on whether the customer furnished Lever Brothers with newspaper advertising, handbills, or store displays. ${ }^{49}$ Until October of 1960 , it was thought that rendering of services could

37282 F.2d 917 (6th Cir. 1960), appeal dismissed per curiam; 366 U.S. 269 (1961).

38 This does not mean, however, that higher prices charged to consignees' competing customers may not violate section 2(a).

39 Russellville Canning Co. v. American Can Co., 87 F. Supp. 484, 498-99 (W.D. Ark. 1949), rev'd, 191 F.2d 38, 56 (8th Cir. 1951).

40 Chicago Seating Co. v. S. Karpen \& Bros., 177 F.2d 863 (7th Cir. 1949).

41 Students Book Co. v. Washington Law Book Co., 232 F.2d 49 (D.C. Cir. 1955).

42 Skinner v. United States Steel Corp., 233 F.2d 762 (5th Cir. 1956).

43 Lambert Pharmacal Co., 31 F.T.C. 734 (1940).

4 Luxor Ltd., 31 F.T.C. 658 (1940).

45 Idaho Canning Co., No. 7495, FTC News Release, May 22, 1961 (consent order).

46 EDWARDS, op. cit. supra note 11, at 156-64 has an interesting discussion. For an earlier mathematical computation of considerable complexity, see Layton, supra note 11. An attempt to hold the standard unconstitutionally vague was unsuccessful in Elizabeth Arden, Inc. v. FTC, 156 F.2d 132 (2d Cir.), cert. denied, 331 U.S. 806 (1946).

47 Guide 7.

48 FTC v. Simplicity Pattern Co., 360 U.S. 55,61 n.4 (1959). AtT'y Gen. NAT'L Comm. ANTITRUST REP. 189-90 (1955) also has registered approval.

49 Lever Bros. Co., 50 F.T.C. 494 (1953). See also examples in Guide 9. 
be used to supplement payments in order to satisfy the requirements of proportionality. ${ }^{50}$ However, an FTC Hearing Examiner's opinion of that month ruled that such a combination was not allowable. 51

A comprehensive plan should be proferred openly by the supplier, 52 although general publicity in a trade journal may not be sufficient notice. 53 The seller has an affirmative duty not only to inform all customers but also to police the buyer's performance under the plan.54 "Reasonable precautions" must be taken to see that the services furnished are not being overpayed and, further, are being properly used. 55 Recent Commission complaints have frequently charged payment in excess of value accrued. 56 Finally, the courts and Commission have both determined that the burden of showing the reasonableness of the plan and the availability of its proportionality is on the respondent. 57

Despite the usual criticism, allowances and services are more broadly available than before. When such payments are made, care is usually taken to see that the advertising is actually provided. Although it is true that it is difficult to engage in selective advertising, whether or not competition is harmed, some

so Guide 9, ex. 2.

51 The Hearing Examiner's holding is, of course, far from conclusive, for the FTC did not expressiy pass on the point. Exquisite Form Brassiere, Inc., No. 6966, FTC, October 31, 1960 (Tait, dissenting).

52 Guide 6; Liggett \& Myers Tobacco Co., No. 6642, FTC, September 9, 1959. The Commission, however, once failed to prove its case against a food supplier who had not announced a plan. Atalanta Trading Corp., 53 F.T.C. 565, 570 (1956), rev'd sub nom. Atalanta Trading Corp. v. FTC, 258 F.2d 365, 372 (2d Cir. 1958).

53 Exquisite Form Brassiere, Inc., No. 6966, FTC, October 31, 1960. See Shniderman, supra note 8, at 417 for a discussion of the practical problems this ruling presents.

54 Guide 11. ss 1 bid.

56 See, e.g., Regina Corp., No. 8421, FTC News Release, June 20, 1961; Giant Food, Inc. No. 6459, FTC, June 1, 1961. An earlier egregious example is American Co-op. Serum Ass'n v. Anchor Serum Co., 153 F.2d 907 (7th Cir.), cert. denied, 329 U.S. 721 (1946), where payments in 1937 were \$8,666, while expenditures amounted to only \$648.

A related problem occurs in advertising promotional schemes through newspapers. National rates are always in excess of local rates, with the result that an cverpayment invariably occurs when the customer is reimbursed at the higher rates. But the national rates are what the seller would have to pay were he himself placing the ads. See Shniderman, supra note 8, at 419-20; see generally FELDMAN \& ZORN, op. cit. supra note 11, at 3-45; cf. the private suit under the Sherman Act, alleging that such a practice initiated by a newspaper was evidence of intent to monopolize, in Scott Publishing Co. v. Columbia Basin Publishers, Inc., 293 F.2d 15, 22 n.14 (9th Cir. 1961).

57 State Wholesale Grocers v. Great Atl. \& Pac. Tea Co., 258 F.2d 831, 838 (7th Cir. 1958) ("The burden is upon the party who seeks the protection of the exception. ..."); Liggett \& Myers Tobacco Co., No. 6642, p. 6, FTC, September 9, 1959 ("The question of the availability of payments to others on proportionally equal terms is a matter of defense to be established by the respondent upon the prima facie showing of discriminatory payments...."). See the related practice challenged by the FTC in North American Phillips Co., 55 F.T.C. (1958); Westinghouse Elec. Corp., No. 7150, FTC, Oct. 13, 1959. 
workable standards have been evolved so that the businessman need not necessarily rush blindly into illegality. As suggested above, however, problems still remain. It is to four of these areas that this comment now turns.

\section{Special Sales and Brand Names in the Food Industry}

No industry's system of distribution is more closely related to the purposes behind the Robinson-Patman Act than the food industry. Advertising is a crucial factor in the expenses of both manufacturers and retailers. 58 In addition to direct advertising in national magazines, on radio and television, and in newspapers, many food manufacturers furnish the retail trade with booklets and leaflets, aid in the preparation of window and store displays, and share in the cost of dealer advertising. 59 Part of the solution to the problems of independent retailers who could not obtain the tremendous allowances accorded chains like A\&P60 was found in the passage of section 2(d).

Because they are peculiarly appropriate to institutional changes and market strategies in the food industries, advertising allowances have become even more prevalent since the passage of the act.61 Efforts to exploit the value of trademarks result in allowances to induce distributors to push such goods. The increasing emphasis on packaged and processed foods underlines the importance of brand names. The development of supermarkets and self-service stores proves to the supplier and his retailer the necessity for persuading the housewife of the quality and desirability of his product before she enters the store. Special sales, "anniversary sales," and the promotion of brand names, then, add a special fiavor to the impact of section 2(d).

The special sale for the first time was reviewed by a federal court in Atalanta Trading Corp. $v$ FTC. 62 In the Washington, D.C. area, Atalanta had given Giant Food Shopping Center an allowance of $\$ 500$ to push "Unox" pork shoulder picnics for the Fourth of July, 1954. Five months after its allowance to Giant a single sale of pork shoulder picnics had been made to a different customer without an allowance. An allowance had also been given Giant to promote special gift-wrapped "Unox" canned hams for the Christmas holiday, but was not afforded on a sale of "Unox" canned hams, without the special packaging, eight months earlier. Atalanta finally had sold to Giant "Unox" branded precooked Canadian bacon in May 1955, with which it gave another advertising allowance. Bacon in a different form, without an allowance, had been sold at the same time to other retailers, but not in the Washington area. The first two promotions were solicited by Atalanta, while the third

58 Fulda, Food Distribution in the United States, The Struggle Between Independents and Chains, 99 U. PA. L. REv. 1051, 1084-94 (1951).

i9 See FTC, Report on Distribution Methods ANd Costs, pt. 1, 26, 27 (1944).

60 From Standard Brands, Inc. alone, A\&P received \$12,000 a month in 1935. Id. at 15.

61 Edwards, The Price Discrimination Law 171-74 (1959).

62258 F.2d 365 (2d Cir. 1958). No appeal was taken. 
arrangement was initiated by Giant as part of its "19th Anniversary Sale."

The Commission had analyzed the promotions on the theory that all could be considered as allowances on pork products. ${ }^{63}$ The Second Circuit in dismissing the complaint rejected this classification and also offered an alternative ground.64 Both holdings turned on an examination of the requirement of "competing." The "products and commodities" involved were held not to be competing because they were not of "like grade and quality." Similarly, the different sales of the same product were not "competing" since the time differential was too disparate. Thus the case extends to the seller the right to limit product coverage in a promotion, tacitly acknowledges in some circumstances "spot" promotions and special sales, and specifically reads into 2(d) the limitation of "like grade and quality."

The circuit court's stress of the time interval between sales as "a determining factor" 65 may raise some difficulties in future application. Since no real standard was suggested, except that the Commission's blithe statement of "six or eight months" was too broad, the specter of a case to case determination seems a possibility. Some guides, however, appear possible. An earlier Commission opinion ${ }^{66}$ rejected a dress manufacturer's attempt to avoid the section because the favored customer received an allowance in January, while the unbenefitted customer, although buying in March, ordered no dresses in January or February. Because the allowances accorded in that case were part of an Easter promotion, it thus appears that seasonal patterns in particular industries can expand or contract the necessary time interval. Furthermore, "spot" promotions on perishable goods may fare better than pushing hard goods which can remain on the shelves for longer periods of time.

The Atalanta decision further limited the trend of Commission decisions expanding the phrase "like grade and quality." Although confusion as to the meaning of the phrase was apparent, ${ }^{67}$ until 1956 the FTC usually applied the test of physical comparison of the goods. 68 In the General Foods case, 69 however, the FTC held that different grades of coffee when sold under a common brand created a presumption of "like grade and quality." A private suit in 1951 aided a broad interpretation by the FTC, when "like grade and quality"

${ }^{63}$ Atalanta Trading Corp., 53 F.T.C. 565 (1950.

${ }^{64}$ Atalanta Trading Corp. v. FTC, 258 F.2d 365 (2d Cir. 1958).

${ }^{65} \mathrm{Id}$. at 372.

${ }^{66}$ Kay Windsor Frocks, Inc., 51 F.T.C. 89, 96 (1954).

${ }^{67}$ The confusion and inconsistency in Commission application is thoroughly analyzed in Rowe, Price Differentials and Product Differentiation: The Issues under the Robinson-Patman $A c t, 66$ YALE L.J. 1, 9-18 (1956).

${ }^{68}$ Champion Spark Plug Co., 50 F.T.C. 30 (1953); United States Rubber Co., 46 F.T.C. 998, 1006-09 (1950); Hansen Inoculator Co., 26 F.T.C. 303 (1938). See Cassady \& Grether, The Proper Interpretation of "Like Grade and Quality" Within the Meaning of Section 2(a) of the Robinson-Patman Act, 30 So. CAI. L. REv. 241, 244 n.13 (1957).

69 General Foods Corp., 52 F.T.C. 798 (1956). 
was equated with functional interchangeability. ${ }^{70}$ The Hearing Examiner's determination in Atalanta that "ham is ham," 11 however, was decidedly distasteful to the Second Circuit.

The most that can be said of the court's holding on this point is that identical brands, interchangeability, and cross-elasticity of demand do not create a presumption of "like grade and quality." 72 But because the opinion went on to show that there was no cross-elasticity anyway, 73 at minimum the court appears desirous of protecting a seller from having to yield promotions on all his branded products in one line. An earlier statement by the Commission recognizing an advertising allowance that could be confined to "slow sellers" in the dress industry was in accord with this view. 74

It has been suggested that the Second Circuit position on "like grade and quality" is unrealistic in the light of modern market conditions. 75 When a supplier promotes one product carrying his general brand name, it may be that the sale of his like branded products is thereby also increased. Thus a discrimination can result if a producer picks favored retailers to promote a product not available to the retailers' competitors, even though the competing stores carry other "Unox" products. 76 If market analysis could conclusively show that the consumer psychology in the vast majority of cases is tied to "brand monopoly," perhaps it would be true that the seller under Atalanta could adroitly circumvent the purposes of section 2(d). On the other hand, a contrary decision might impair effective and sensible product differentiation, impede product innovations, and impose onerous and expensive obligations on an otherwise valid market strategy. 77

70 Bruce's Juices v. American Can Co., 87 F. Supp. 985, 987 (S.D. Fla. 1949), aff'd, 187 F.2d 919, 924 (5th Cir.), modified on rehearing, 190 F.2d 73, 74 (5th Cir.), cert. dismissed, 342 U.S. 875 (1951). See also the Initial Decisions in Sylvania Elec. Prods., Inc., 51 F.T.C. 282 (1954); E. Edelmann \& Co., 51 F.T.C. 978 (1955). But see ATr'y GeN. NAT'L Comm. ANTITRUST REP. 158 (1955).

7153 F.T.C. at 568.

72258 F.2d at 371.

73 "Simply because bacon and pork come from a common source does not mean they are of like grade and quality. There is no showing they are in the same price range; few people eat bacon for dinner and probably even fewer eat roast pork for breakfast. Similarly pork shoulder meat and ham are two different cuts and price-wise are not competitive. ..." Id. at $371 \mathrm{n} .5$.

74 "The law imposes no requirements that a seller give advertising allowances on all his products if he elects to accord them on one or more articles." Henry Rosenfeld, Inc., 52 F.T.C. 1535, 1545 (1956).

75 Note, "Like Grade and Quality" under \$2(d) of Robinson-Patman Act, 34 N.Y.U.L. REv. 1335, 1337-39 (1959).

76 A supplier, of course, may refuse to deal with any of his customers, assuming the absence of any purpose to create or maintain a monopoly. Naifeh v. Ronson Art Metal Works, Inc., 218 F.2d 202 (10th Cir. 1954). Cf. United States v. Colgate \& Co., 250 U.S. 300, 307 (1919). Accord, Lorain Journal Co. v. United States, 342 U.S. 143, 155 (1951).

$n$ Interesting and difficult problems also arise from the use by a manufacturer of his own brands and the sale of his goods of "like grade and quality" to certain purchasers for resale 
Atalanta's examination of "competing" products and sales suggests a related limitation important to a seller's promotional program. Guide 12 indicates that the supplier can limit the area of his promotion to that in which participating customers sell. Although this means that a national distributor is not required to initiate a promotional plan in Boston because he is "plugging" the same product in San Francisco, the problem of "partial" or "fringe" competition is apparent.78 In Sun Cosmetic Shoppe, Inc. v. Elizabeth Arden Sales Corp. ${ }^{79}$ the court wanted to know, for purposes of damages, to what extent customers of a New York retailer had been diverted to the favored New Jersey stores. Although it can be argued that the omission of the word "competing" from section 2(e) indicates a broader congressional purpose than 2(d), Sun Cosmetic, where demonstrators were being furnished, suggests that this important limitation is present in section 2(e) as well. 80

Atalanta and related cases thus raise the issues of "spot" promotions and special sales when goods are initially determined to be of "like grade and quality." It may be, however, that Atalanta will only apply when product acceptability is not prevalent. Although not confined by its language to that situation, the case in fact involved de minimis sales of newly introduced food specialties. ${ }^{81}$ Business firms selling a general line traded under a uniform brand name with a close subsitutionary relationship can expect the FTC to continue finding a violation when allowances given one customer are not proportionally available to others. ${ }^{82}$ That Atalanta has completely immunized the

under private brands. See the 2(a) Commission cases, United States Rubber Co., 28 F.T.C. 1489 (1939); Standard Oil Co., 41 F.T.C. 263 (1945). See generally Austin, Price DisCRimination and Related Problems under the Robinson-Patman Act 129-30 (rev. ed. 1959); Rowe, supra note 67, at 10-12.

78 Guide 10 , Note specifically states that the seller "must be careful not to discriminate against customers located on the fringes but outside the area selected for the special promotion...." This line may be even more difficult to draw than one involving time. $C f$. in another connection the problems raised by Nachman v. Shell Oil Co., TRADE REG. REP. (1945 Trade Cas.) II 57361 (D. Md. 1945).

79178 F.2d 150 (2d Cir. 1949) (L. Hand, J.).

80 There may be, however, a significant difference between proof in a private suit and the area of competition in a FTC proceeding. See further discussion of this problem in text accompanying note 151 infra.

8153 F.T.C. at 567 (testimony of Atalanta's vice president); 258 F.2d at 368 ("On the basis of these three small and isolated transactions the Commission entered a sweeping cease and desist order which places Atalanta in jeopardy of contempt if it hereafter violates Section 2(d) in any fashion in any place in the country.") (Emphasis added.)

Whether de minimis or lack of public interest is a complete defense to a Robinson-Patman Act charge is not altogether clear. See Webb-Crawford Co. v. FTC, 109 F.2d 268, 269 (5th Cir.), cert. denied, 310 U.S. 638 (1940); Rocky Mountain Wholesale Co., 52 FTC. 1484 (1956) (amount involved was \$35.76). A recent answer to an FTC charge alleging violation of $\S 2$ (d), however, alleges de minimis sales. T. W. Holt \& Co., No. 8371, FTC News Release, June 9, 1961 .

82 A Commission order in June 1961 rejected Giant Food's attempt to justify its inducement of promotional allowances for the same "19th Anniversary Sale" present in Atalanta, 
national brand distributor from the requirement of proportionality on special sales is not yet manifestly evident.

\section{The "Chain Lightning" Promotion and Indirect Benefirs}

Of particular promotional importance to the grocery industry is the use of in-store advertising-whereby suppliers pay in whole or in part for counter and window displays, shelf positions, dump displays and the like. These point-ofsale promotions played an interesting part in the question as to whether certain retailers were indirectly benefitted by payments to a third party in $P$. Lorillard Co. v. FTC. 83

In 1950 the sale of broadcasting time had become more difficult than usual, with the result that broadcasting companies developed promotional schemes to enable them to sell radio and television time to manufacturers and sellers of grocery products. These plans, variously labelled "Chain Lightning," "Supermarketing," and "Sell-A-Vision," only benefitted those chains which the broadcasting companies selected. The plans first necessitated a contract with certain chains whereby free radio and television time was offered in consideration for the chains' agreement to conduct a specified number of week-long promotional displays of as yet unspecified products in their stores. The broadcasting companies then solicited food suppliers to purchase radio or television time, offering, as an added inducement, a right to the in-store promotions already under contract. Although the brochures and circulars sent to the manufacturers contained details of the previous firm commitments by the particular chains, the contracts between the producers and broadcasting companies were at the standard rates and contained no reference to any other agreement.

The Third Circuit agreed with the Commission that the series of contracts should be viewed as a whole, and held that the real question involved was whether the sellers "have made payments to someone which actually are of benefit to their customers. ..." 84 The court also rejected the argument that payments are not made for the benefit of a customer within the meaning of 2(d) unless the seller either intends to benefit the customer or has reason to

on the basis that disfavored competitors did not buy wares of "like grade and quality" advertised in the Sale. Giant Food, Inc., No. 6459, FTC, June 1, 1961. The opinion stated that the requisite presumption was present, for "the articles and brands advertised by Giant patently included many whose names are household bywords throughout the country." Id. at 4. (Emphasis added.) Another recent FTC complaint against "Anniversary Sales" can be found in Yakima Fruit \& Cold Storage Co., No. 7718, FTC, October 10, 1960.

A charge under the section might be brought against a Delmente promotion of sliced peaches not accorded to competing customers who carried only haif-peaches. Whether the FTC would complain if Delmonte promoted peaches but not pears is more difficult to assess.

83267 F.2d 439 (3d Cìr.), cert. denied, 361 U.S. 923 (1959).

84 Id. at 444. 
know that some benefit to him will proximately result.85 One judge dissented on the ground that the execution of the agreements by the food suppliers was not a contingency upon which the right of the chains to air time depended; thus the "benefit" to the chains was too causally remote. 86

A similar "indirect benefit" was present in a more recent case, Swanee Paper Corp. v. FTC. 87 By the device of payments to a third party, one retailer received the benefit of almost free advertising. The dispute here arose out of a series of arrangements involving Swanee, a manufacturer of paper products, Grand Union, a customer of Swanee operating retail food stores, and Douglas Leigh, Inc., the owner and operator of a giant electric animated advertising sign located in Times Square. In 1952 Grand Union accepted the use of one panel of the sign for a nominal fee of $\$ 50$, in return for securing fifteen participating advertisers to use the other panel. Swanee agreed with Grand Union to become one of the participating advertisers, and as part of the discussions with Grand Union, a schedule of in-store promotions of Swanee's products was arranged. Although again the payments by the supplier were not made directly to the chain store, the Second Circuit had no difficulty finding them to be for the benefit of the retailer, and held that such payments were made in consideration of services or facilities rendered "by or through" Grand Union. 88

85 "This section of the Act does not concern itself with motive or intention. It is only concerned with the consequences which flow from an act." Ibid.

Lorillard attempted to argue that the in-store promotions were nothing more than a "premium," added to the sale of air time by the broadcasting companies. Brief for Petitioner, pp. 23-24. The practice of offering a free tube of shaving cream with every sale of a safety razor, however, does not seem in jeopardy under the decision. When a customer buys a razor kit and accepts the premium, the benefit to the maker of the shaving cream seems too remote to impose the burden of proportionality. For the Commission definition of "premium," see Walter J. Black, Inc., 50 F.T.C. 225 (1953). The premium problem has arisen in another context under section 2(a). Cf. FTC v. Anheuser-Busch, 363 U.S. 536 (1960).

86 'If the Commission's conception of 'benefit' is adhered to, the only way in which the petitioner could have escaped the toils of the Clayton Act during the period when the broadcasting companies were offering in-store promotions would have been either to forego completely advertising over the air through the broadcasting companies offering the promotions, or to buy air time for all of petitioner's customers on a basis proportionately equal to that on which the broadcasting companies had allotted air time to the chains." 267 F.2d at 448. (Emphasis added.)

87291 F.2d 833 (2d Cir. 1961).

88 Swanee's Brief unsuccessfully attempted to distinguish Lorillard on four grounds: that any benefit was fumished by Douglas Leigh, and not, as in the earlier case, by the supplier; that Grand Union was under no contractual obligation to furnish in-store promotions; that nothing in the contract between Grand Union and Douglas Leigh was an inducement for Swanee to enter into a rental agreement; and finally, that whereas in Lorillard the grocery suppliers were informed of the arrangements between the broadcasting companies and the chains, Swanee had no knowledge of the arrangement between Grand Union and Douglas Leigh. Brief for Petitioner, pp. 30-38. It does not appear that Swanee's counsel was seriously convinced they could avoid the precedent of Lorillard, for twenty-six of the thirty-eight page brief was concerned with modification of the order and establishing discontinuance of the practice. 
Despite allegations that the FTC in Lorillard was "experimenting with an unprecedented theory," 89 both cases seem to be sound applications of the statutory wording in 2(d). The language of the section does not specify either the means whereby customers can be favored or the type of favoritism condemned. In referring to a "payment of anything of value to or for the benefit of a customer" for services "by or through such customer," the section necessarily carries the connotation that the unlawful acts could be accomplished by using a third party or with the aid of an intermediary. 90

The concept of an "intermediary," however, is usually associated with the brokerage provision, section 2(c). The intervention of a third party between the seller and the favored buyer should not necessarily defeat the application of section 2(d). Although the original FTC theory in Lorillard asserted an "agency" relationship between the broadcasting companies and the suppliers, 91 the Hearing Examiner ruled that the discriminating suppliers in effect "adopted" the original series of contracts with the chains. 92 The Third Circuit properly went one step further and refused to view the different contracts separately, but instead examined all the surrounding circumstances together. The substance of respondents' actions, not their form, has governed Commission and court decisions before. 93 To decide otherwise might provide large loopholes for easy avoidance of the act.

One anomalous problem is evident, however, for in Lorillard the Commission complaint against the supplier under 2(d) collaterally implicated the network sale of radio and television time, which standing alone apparently could not be directly attacked under the Robinson-Patman Act. In the FTC's opinion, sales of advertising space 94 and broadcast time 95 are beyond the coverage of the act, as "commodity" is limited to merchandise in the conventional sense

89 Rowe, The Evolution of the Robinson-Patman Act: A Twenty-Year Perspective, 57 Colum. L. Rev. 1059, 1084 n.155 (1957); see Rowe, How to Comply with Sections 2(c)-(f), in CCH ANTITRUST LAW SYMPOSTUM 124, 135-36 n.47 (1957).

90 More essential to the question of "benefit" in the section is the State Wholesale Grocers case, which could be interpreted as prohibiting all nonproportional payments without regard to any benefit to the recipient customer. State Wholesale Grocers v. Great Atl. \& Pac. Tea Co., 258' F.2d 831, 837 (7th Cir. 1958), cert. denied sub nom. General Foods Corp. v. State Wholesale Grocers, 358 U.S. 947 (1959). See Note, 72 HARV. L. REv. 1389 (1959). It is more likely, however, that the court may have found a general benefit to A\&P in the form of good will and patronage. 258 F.2d at 834.

91 Appendix to Petitioner's Brief, p. 3 a.

92 Id. at p. 133a.

$23 \mathrm{See}$, e.g., the disregard of corporate form in the brokerage cases, Webb-Crawford Co. v. FTC, 109 F.2d 268 (5th Cir.), cert. denied, 310 U.S. 638 (1940); Mississippi Sales Co., 30 F.T.C. 1282 (1940); Thomas Page Mill Co., 33 F.T.C. 1437 (1941). Form has not governed in the "indirect customer" area either. See part IV infra.

9481 CONG. REC. APP. 2336 (1937).

${ }^{95}$ Report of the Antitrust Subcommittee on the Television Broadcasting Industry of the House Co:nmittee on the Judiciary, 85th Cong., 1st Sess. 66 (1957). 
of something tangible. Nevertheless, judicial dicta indicate that the issue is still open. When the Government conceded in Times-Picayune that advertising space was not a commodity under Section 3 of the Clayton Act, the Supreme Court commented, "We express no views on that statutory interpretatation." 96 Thus, under prevailing interpretations, although section 2(d) would not have been applicable to the transactions between CBS and the suppliers or CBS and the grocery chains, the combination of contracts brought the supplier under the section.

The Swanee opinion made clear that further judicial construction of "indirect benefit" may still arise. The court stated that, "There may be situations where payments by a supplier to a third person indirectly benefit a customer of the supplier and yet are not 'for the benefit' of the supplier within the meaning of Section 2(d)."97 At least where the benefit is wholly dependent upon a payment and the customer is an essential party to the entire transaction, the Commission will have no difficulty in finding a violation. The "situations" which the Swanee court may have had in mind are probably tied to that court's further declaration that "we need not decide the ... question" 98 of whether a violation can exist if the respondent did not have knowledge that a customer was being benefitted. 99 There may then be some limitation on how "indirectly" removed a benefit can be if innocence is interpolated into the section.

The clearest example of an "indirect benefit" can be seen in the common practice in certain industries 100 of making payments of "push money" directly to salesmen, clerks, or demonstrators to devote special effort to the sale of the payor's products. Any argument that only the salesmen are benefitted and not their employers has been given short shrift by the Commission. 101

A final note is warranted by the obverse of Swanee, where in Grand Union Co., 102 the Commission for the first time held that a buyer's knowing induce-

96 Times-Picayune Publishing Co. v. United States, 345 U.S. 594, 609-10 n.27 (1953). Accord, Syracuse Broadcasting Corp. v. Newhouse, 236 F.2d 522, 527 (2d Cir. 195ด. Cf. Northern Pac. Ry. v. United States, 356 U.S. 1 (1958).

CBS appeared as amicus before the Third Circuit. The dissenting judge felt that because the sales promotional plan of the broadcasting companies might have been economically undesirable, or that the companies were beyond the reach of present law, was no reason for making "a whipping boy" out of the respondent. 267 F.2d at 448.

97291 F.2d at 836, citing the dissent in Lorillard.

98 Id. at 836.

99 The court did not have to decide the question for the record was found to have fully supported the Commission's conclusion that Swanee knew or should have known it was benefitting Grand Union.

100 The practice is especially prevalent in the cosmetics and related industries.

101 Exquisite Form Brassiere, Inc., No. 6966, FTC, October 31, 1960 (prize monies). The most recent complaint against disproportionate payments to store personnel can be found in Regina Corp., No. 8421, FTC News Release, June 20, 1961.

102 No. 6973, FTC, August 12, 1960 (Tait, dissenting). 
ment of discriminatory advertising allowances constitutes an unfair trade practice proscribed by Section 5 of the Federal Trade Commission Act. 103 Grand Union, like Swanee, argued that section 2(d) was not applicable to the sign program since payments made by the suppliers were for services rendered by Douglas Leigh and any benefits Grand Union received were in consideration for services rendered Douglas. This attempt to "artificially fragmentize and compartmentalize an essentially unitary transaction" 104 was equally unsuccessful. The co-ordinated industry-wide attack against the buyer in Grand Union and the supplier in Swanee will prove to be an important development in the indirect benefit situation as well as in the traditional direct benefit tender of discriminatory allowances or services under sections 2(d) and 2(e). 105

\section{THE "INDIRECT CUSTOMER"}

One real danger to an intelligent sales operation is hidden in the concept of who is a customer or a purchaser under sections 2(d) and 2(e) of the act. Guide 3 informs the supplier that:

A "customer" is someone who buys directly from the seller or his agent or broker. Sometimes someone who buys from the customer may have such a relationship with the seller that the law also makes him a customer of the seller. In these Guides, the word "customer" which is used in section 2(d) of the law includes "purchaser" which is used in section 2(e).

The Commission theory of interchangeability has particular significance for 2(d), since payments prohibited by that section are payments to "a customer of such person," meaning a customer of the person.making the payment, whereas "purchaser" in 2(e) is not so limited.106 But the Commission and to

10352 Stat. 111 (1938), as amended, 15 U.S.C. $\$ 45(a)$ (1) (1958).

104 Grand Union Co., Opinion p. 11.

105 The omission of "services and facilities" from section 2(f)'s condemnation of a knowing inducement or reception of a "discrimination in price" was explained as inadvertant by the draftor of that section. Dunn, Sections $2(d)$ and $(e)$, in CCH RoBInson-Patman ACT Symposium 55, 61 (1946). Although the FTC apparently felt that they could not proceed against the buyer under 2(f) for inducing a 2(d) violation, the Supreme Court in Automatic Canteen left the question open: "We of course do not, in so reading \$2(f), purport to pass on the question whether a 'discrimination in price' includes the prohibitions in such other sections of the Act as §§ 2(d) and 2(e)." Automatic Canteen Co. v. FTC, 346 U.S. 61, 73 n.14 (1953).

The Grand Union proceeding has not gone without criticism. See Oppenheim, Guides to Harmonizing Section 5 of the Federal Trade Commission Act with the Sherman and Clayton Acts, 59 MicH. L. REv. 821, $839-45$ (1961); Note, Section 5 of the Federal Trade Commission Act and Robinson-Patman Act Policy, 13 STAN. L. REV. 657 (1961). However, the principle of Grand Union was applied in American News Co., No. 7396, FTC, January 10, 1961. For additional use of this technique see the proceedings against both buyers and sellers in a number of industries, including groceries, pipe and plumbing fixtures, and toys, cited in Kintner, The Federal Trade Commission in 1960-Apologia Pro Vita Nostra, in CCH ANI1TRUST LAW SYMPOSIUM 21, $32 \mathrm{nn} .9-11$ (1961).

${ }^{106}$ See AUSTIN, op. cit. supra note 77, at 134-35. 
some extent the courts have not construed 2(d) to be limited to purchasers from the seller charged with a violation. This is the so-called "indirect purchaser" or "indirect customer" concept. A person who as a matter of contract law will not be considered a customer may be deemed a "customer" under the act, just as the technical rules of contract law were held not to be binding in the Lorillard and Swanee cases.

The notion of the "indirect customer" has generally arisen in the context of other sections. Fair Trade contracts and the maintenance of a pricing policy by the seller on his products made retailers who purchased from jobbers "purchasers" under 2(e).107 In the Kraft-Phenix Cheese Corp. case, retailers were deemed "indirect purchasers" of the supplier who "by personally soliciting them and by making effective its price policies and schedules" 108 had taken over the normal tasks of its intermediate distributor organization. Thus rigid franchise control 109 and resale price maintenance or perhaps suggested resale prices when combined with other retailer contacts like missionary work, drop shipments, and the like will be enough to create a customer relationship.110

An initial construction of section 2(d) in this regard was made in Kay Windsor Frocks, Inc.111 There the FTC pierced the sales transactions and found retailers buying through a Mutual Purchasing Syndicate "customers" of the dress manufacturer.112 Indicative of the difficulties of definition, however, was the Commission's refusal to define "customer" in the order, for the problems "attendant to [such] an undertaking . . . are obvious." 113

Those cases, however, should be distinguished from the situation of whether, absent supplier-retailer contact and control, a promotional allowance to a direct buyer has to be offered on proportionally equal terms to wholesalers whose customers compete with the direct buyer, or to the wholesaler's customers who so compete. The Elizabeth Arden case held that services or facilities furnished a direct purchaser had to be offered on proportionally equal terms to competing "indirect purchasers" under 2(e).114 In Krug v. Inter-

107 Luxor, Ltd., 31 F.T.C. 658, 662-63 (1940).

10825 F.T.C. 537 (1937) (section 2a).

109 See the Spark Plug cases, i.e., Champion Spark Plug Co., 50 F.T.C. 30 (1953); General Motors Corp., 50 F.T.C. 54 (1953); Electric Auto-Lite Co., 50 F.T.C. 73 (1953).

110 See, e.g., Ronson Corp., 55 F.T.C. 1017 (1959). Charles Wesley Dunn stated that the situations of sufficient direct merchandising relation included "where a manufacturer suggests a resale price to or by the retailer; or where he solicits order from the retailer, to be filled by a wholesaler; or where he makes drop shipments to the retailer, for the account of a wholesaler; or where he gives the retailer any merchandising advice or assistance whatever." Dunn, supra note 105 , at 63.

11151 F.T.C. 89 (1954).

112 Direct shipping of merchandise, direct billing and extending credit were sulficient to establish the necessary course of dealing. Id. at 95 .

113 Id. at 97.

114 Elizabeth Arden v. FTC, 156 F.2d 132, 135 (2d Cir. 1946), cert. denied, 331 U.S. 806 (1947). 
national Tel. \& Tel. Corp., a district court in 1956 held that a promotional allowance paid a direct buying retailer must be made available to wholesalers whose customers compete with the retailer receiving the allowance.115 The Krug court reasoned that the purpose of 2(d) was to place discriminatory allowances on the same basis as price discriminations prohibited by 2(a).116 Thus, a payment is prohibited under 2(d) if, had it been a price discrimination, it would be unlawful under 2(a). The finding of a violation in Krug because of the wholesaler's "competing customers" must have rested on the unspoken assumption that "customers competing" in the statute includes those buying from the purchaser. It would appear from this case, then, that the supplier must make payments available to wholesalers and retailers buying from the wholesalers if he wishes to make payments to a retail chain purchasing directly. 117

Considerable doubt was cast on this reasoning, however, in Klein v. Lionel Corp., ${ }^{118}$ a section 2(a) case. The manufacturer had sold to a wholesaler and to certain chains at the same price, but plaintiff retailer buying from the wholesaler alleged he was discriminated against, because the wholesaler's price with customary markup was necessarily higher than the chain store price. The court ruled that a retailer buying through a supplier's wholesaler was not a "purchaser" from the supplier. While Krug can be said to be concerned merely with the discriminatory impact of a price and allowance differential quoted and afforded direct purchasers, in Lionel no such differential among direct purchasers existed.119 Lionel, however, definitely repudiated the "indirect customer" concept in private damage litigation where the plaintiff raised the question of resale price maintenance. For Lionel controlled resale prices to the extent that it fixed a minimum under the Delaware Fair Trade statute. ${ }^{120}$ The court rejected the earlier Commission cases to the contrary, ${ }_{121}$ stating that "a retailer who buys from a jobber does not become a purchaser under Section 2(a) ... merely because the products he deals in are Fair Traded."122

When the cigarette industry's methods of distribution came under attack, the FTC finally. faced the issue under section 2(d). The first series of cases

115142 F. Supp. 230 (D.N.J. 1950).

$116 \mathrm{Id}$. at 236.

117 See Note, 72 HaRv. L. Rev. 385 (1958). Cyrus Austin has also agreed. Austin, op. cit. supra note 77, at 135; for the policy reasons, see Austin, Price Discrimination and the Small Business Man, in 16 ABA ANTITRUST SECTION 94, 101-02 (1960).

118237 F.2d 13 (3d Cir.), affirming 138 F. Supp. 560 (D. Del. 1956).

119 See the discussion in Rowe, Discriminatory Sales of Commodities in Commerce: Jurisdictional Criteria under the Robinson-Patman Act, 67 YALE L.J. 1155, 1160-61 (1958).

120 DEL. CODE ANN. tit. 6, § 1901-07 (1953).

${ }_{121}$ Luxor, Ltd., 31 F.T.C. 658 (1940); Kraft-Phenix Cheese Corp., 25 F.T.C. 537 (1937). 122237 F.2d at 16. 
charged the cigarette manufacturers with establishing retailers as their own customers by means of direct solicitation through missionary salesmen, although delivery was through wholesalers. ${ }^{123}$ These cases were dismissed in 1948 for lack of evidence. In 1959, however, the Commission in Liggett \& Myers 124 by a two to one decision (Chairman Kintner and Commissioner Secrest not participating) in effect refused to follow Krug by upholding the Examiner's ruling that the tobacco seller did not have more than 800,000 "indirect customers." 125

The seller marketed cigarettes through direct dealing with wholesalers, vending machine customers, and a small number of large retailers. Promotional allowances were afforded the vending machine customers and some of the direct buying retailers, but were not available to any wholesalers. The supplier's contact with the alleged "indirect customers" who bought through wholesalers included the employment of missionary men who visited some of these outlets sporadically through the year arranging point-of-sale advertising and displays. The missionary men also carried emergency stocks of cigarettes to fill short supplies. The Examiner, however, refused to find the necessary contact, and instead stressed that Liggett \& Myers did not have any control over the prices at which wholesalers sold to the retailers.126

On appeal to the Commission, the FTC counsel supporting the complaint did not argue the indirect customer holding, although Commissioner Kern in dissent felt that Krug should be followed. Instead, the main contention of counsel was directed towards establishing competition between the vending machine customers and the wholesalers. On this point the Commission held that vending machine operators and the wholesalers did not cater to the same class of customers and the functions each performed were significantly enough different so that they were actually not in competition.127 This aspect of the case is important, for perhaps the trial staff felt that, if they could not establish competition between the vending machine customers and the wholesalers, retailers purchasing through the wholesalers did not warrant the protection of

${ }^{123}$ See, e.g., P. Lorillard Co., 44 F.T.C. 1180 (1948); Liggett \& Myers Tobacco Co., 44 F.T.C. 1183 (1948).

124 Liggett \& Myers Tobacco Co., No. 6642, FTC, September 9, 1959 (Kern dissenting). 125 For discussion of the proceeding, both favorable and unfavorable, see Barton, Provisions and Provisos, in CCH ANTITRUST LAw Symposium 94, 105-07 (1960); Murray, The Robinson-Patman Act: A Sampling of Advocacy, 10 Buffalo L. REv. 336, 350-51 (1961); Shniderman, Collateral Discriminations under the Robinson-Patman Act-Section 2(c), (d) and (e), in 17 ABA ANIITRUST SECTION 410, 416-17 (1960); Austin, supra note 117, at 101-02.

126 Liggett \& Myers Tobacco Co., No. 6642, FTC, November 26, 1958 (initial decision). The lack of control over wholesale prices should be contrasted with the earlier charge against the tobacco companies, where orders that missionary men secured were allegedly at prices named by the manufacturer. See note 123 supra.

127 This holding was somewhat surprising since it was clear that there was competition for outlets in bars and grills, where the retailer, if he installed a vending machine, would stop dealing with the wholesaler. 
payments proportional to that afforded the vending machine operators.

Liggett \& Myers, then, in its broadest interpretation may be read as requiring some fair trading activity, regular drop shipments and missionary men work, and a measure of control over pricing policies before an "indirect customer" will be found. Alternatively, anything more than just minor missionary work might bring the supplier under the ambit of the section. The FTC may have recognized the impracticality of forcing the supplier to proportionalize payments to 216 vending machine customers among 800,000 retailers. $128 \mathrm{But}$ practical economics aside, the issue remains alive and the hazy outline of who is an "indirect customer" still remains to be sketched in.

Elizabeth Arden and Krug, however, may still have some vitality, despite Lionel and the Commission affirmance but not discussion of the Examiner's ruling in Liggett \& Myers. When a distribution system approaches being a mere conduit, it is clearly appropriate to invoke the "indirect customer" theory. 129 But when the retailer attempts to establish a customer relationship with the supplier only because he is competing with a direct buyer, the use of 2(d) may not be warranted. The Commission has never urged this theory of the private suits, for it has only found an indirect customer when it feels some degree of control over the transactions or sufficient contacts with the retailer are present. The language of the statute suggests that section 2(d) should be applied only in the latter situations.

\section{The Meeting-Competition Defense}

It is suggested that the first problem the Supreme Court will agree to pass on under section 2(d) is also the most puzzling and troublesome. That is, whether the meeting-competition defense of section 2(b), admittedly available under section $2(\mathrm{e}), 130$ is also available in a $2(\mathrm{~d})$ proceeding. It is clear that a literal reading of section $2(b)$ indicates that it only applies to the seller's furnishing of services or facilities:

[N]othing herein contained shall prevent a seller rebutting the prima facie case ... by showing that his lower price or the furnishing of services or facilities to any purchaser or purchasers was made in good faith to

128 Other practical problems are suggested in Shniderman, supra note 125, at 416-17.

It does appear, however, that concessions might be manipulated to direct buying chains to frustrate the nondiscriminatory purpose of the section. Perhaps in some cases a contrary ruling in line with the suggestion in Krug might be a desirable result, for it is the retailers who need protection against the competing chains that can buy directly more easily.

129 See American News Co., No. 7396, FTC, Jan. 10, 1961, which describes the distribution system for magazine and paperback books, concluding that the intermediary was only a conduit.

130 Guide 14. No proceeding to reach the federal courts has turned on such a defense by a seller charged with violation of $\S 2(e)$. In the Arden case, however, the defense was offered and rejected as inconsistent with the facts. Elizabeth Arden, Inc. v. FTC, 156 F.2d 132 (2d Cir. 1946). Cf. FTC v. Simplicity Pattern Co., 360 U.S. 55, 67 (1959) (dictum). 
meet an equally low price of a competitor, or the services or facilities furnished a competitor. ${ }^{131}$

The plain meaning of the words, however, has not always been evident to those administering the statute.

The issue in its pristine form arose in the Carpel case, where a Hearing Examiner treated the defense substantively, 132 but found against the respondent. The seller's methods were held to be an aggressive rather than a defensive measure to meet specific loss of sales. 133 The same Hearing Examiner's determination of the availability of the defense, however, was held to be error by the Commission in 1956 in Henry Rosenfeld, Inc. ${ }^{134}$ The FTC position had been foreshadowed in a brokerage provision decision by the Third Circuit.135 Considerable confusion regarding the validity of this determination was fostered by the inconsistent positions taken by the Commission in its 1959 briefs before the Supreme Court in Simplicity Pattern. As petitioner in that case it asserted that "The proviso to $\S 2$ (b) clearly creates a meeting-competition defense to $\S \S 2(d)$ and (e) as well as to $\S 2(a)$." 136 Realizing the danger of such a statement, the Commission on the cross-appeal backtracked, stating, "It is not clear whether $\S 2(\mathrm{~b})$ and its proviso apply also to charges under $\S 2(\mathrm{~d})$." 137 The 1960 Exquisite Form Brassiere, Inc. case, with one Commissioner dissenting, reaffirmed the holding that the 2(b) defense is available under section 2(e) but not under 2(d). 138 Since a petition for review of the FTC's decision is pending, ${ }^{139}$ it would be helpful to marshal the arguments on both sides before making any determination on the merits.

Of considerable importance in favor of the Commission's stand, of course, is the express language of section 2(b). ${ }^{140}$ In addition, the legislative history

13149 Stat. 1526 (1936), 15 U.S.C. § 13(b) (1958). (Emphasis added.)

132 Carpel Frosted Foods, Inc., 48 F.T.C. 581, 597-98 (1951).

133 This holding was in line with the cases where the defense was rejected in a 2(a) situation. See the discussion in EDWARDS, The Price Discrimination LAW 552 (1959).

134 52 F.T.C. 1535, 1549-52 (1956).

135 "For example the language of paragraph (b) relates to proceedings brought pursuant to the provisions of paragraphs (a) and (e) but are not applicable to proceedings instituted under paragraphs (c) or (d)." Great Atl. \& Pac. Tea Co. v. FTC, 106 F.2d 667, 677 (3d Cir. 1939), cert. denied, 308 U.S. 625 (1940) (dicta).

136 Brief for the FTC, p. 17 (No. 406).

137 Brief for the FTC, p. $23 \mathrm{n} .9$ (No. 447). At any rate, the question was in fact immaterial to the issues in both appeals.

138 No. 6966, FTC, October 31, 1960 (Tait, dissenting). This was the first case involving violations of both sections in which the availability of the 2(b) defense was raised.

139 The case is pending in the District of Columbia Circuit. Commissioner Kern has now joined the minority position. See Shulton, Inc., No. 7721, FTC, July 25, 1961. A Florida district court, citing no authority, has on motion upheld the defense. Delmar Constr. Co. v. Westinghouse Elec. Corp., TRADE REG. REP. I 69947 (S.D. Fla. Feb. 24, 1961).

140 See note 131 supra. 
could be termed exiguous at minimum. The "services and facilities" amendment to the meeting-competition defense took form during the Senate debates and culminated in Senate passage of a bill containing only the present section 2(d).141 As initially proposed the defense appeared at the end of the bill, but was later renumbered and placed immediately after section 2(a), then, as now, relating only to direct and indirect price discrimination. ${ }^{142}$ No clear explanation was made by either the Senator or Representative introducing the amendment as to why the language was added, ${ }^{143}$ but discussion of the proviso in Congress appears to have been limited to situations involving price discrimination. Representative McLaughlin, however, did state that the amendment "simply allows a seller to meet not only competition in price of other competitors but also competition in services and facilities furnished."144

Furthermore, it is arguable that the sections are consistent and logical in their independent dealing with specified practices. Obvious differences between a seller furnishing a service or facility and his providing only the remuneration for the various promotional activities of his customers can be shown. For example, in Lorillard, the food supplier could not have furnished free radio and television time, but could pay for its being furnished by the broadcasting companies. Also, a violation of section $2(\mathrm{e})$ has been found in the same case where a manufacturer's practices were not held to violate 2(d).145 Finally, when the sections have been read in pari materia, as for example reading in "commerce"146 and "like grade and quality," 147 such requirements are generally jurisdictional and not substantive.

The contrary position depends on persuading the court of the patent absurdity of reading companion sections independently: Parallel interpretation may be said to be essential to sections expressing the same policy and dealing with essentially the same transactions. "Available" and "accorded," "purchrser" and "customer" are two examples of parallel reading.148 The sections difier only in that they apply to different methods by which services and facilities may be furnished, and this distinction has not always been maintained.149

:41 80 CONG. REC. 8418-19 (1936).

142 Ibid.

i43 See the remarks of Senator Moore in 80 CoNG. Rec. 6435 (1936) and Representative Miller in 80 CONG. REC. 8139-40 (1936).

14480 CONG. REC. 8224-25 (1936. (Emphasis added.)

145 General Foods Corp., 52 F.T.C. 798 (1950).

146 Elizabeth Arden Sales Corp. v. Gus Blass Co., 150 F.2d 988 (8th Cir. 1945).

147 Atalanta Trading Corp. v. FTC, 258 F.2d 365 (2d Cir. 1958).

i48 See AtT'Y Gen. NAT'L COMm. ANTITRUST ReP. 189 (1955).

149 For example, the early Arden cases regarded the furnishing of demonstrators as both a 2(d) and 2(e) violation, since the supplier paid their salaries. Elizabeth Arden Sales Corp. v. Gus Blass Co., 150 F.2d 988 (8th Cir. 1945); Elizabeth Arden, Inc. v. FTC, 156 F.2d 132 (2d Cir. 1946). 
In addition, the legislative history could arguably indicate that the "services and facilities" amendment to 2(b) had to refer to section 2(d), since the amendment was in both the House and Senate bills while 2(d) was present, but before 2(e) was added. Finally, proponents of this view can point to the fact that all writers and commentators prefer the reconciliation of the two sections. 150

By confining its interpretation to the precise language of 2(b), the Commission, however, may be charged with an untenable inconsistency. Nowhere in section 2(e) is "purchasers" qualified by the 2(d) limitation of "competing," although the FTC reads the sections together with regard to this crucial point.151 Ironically, a determination contrary to the FTC position on "competing" would certainly be a strong precedent in favor of the Commission's reading of 2(b) as it relates to 2(d). It is arguable, however, that if "competing" purchasers can be read as a jurisdictional requirement in 2(e), any alleged inconsistency is thereby minimized.

It is submitted that the Commission position on the meeting-competition defense is the sounder of the two alternatives, especially in light of previous Supreme Court decisions. The Standard Oil case in 1950 followed the precise language of 2 (b) in construing that section as a complete defense, 152 despite legislative history clearly indicating that Congress felt the defense was strictly procedural.153 Equally important, the Simplicity Court stated, "We cannot supply what Congress has studiously omitted."154 Since 2(b) refers only to the seller's furnishing of facilities or services and not to the 2(d) situation where the buyer is doing the furnishing, the above quoted language would be difficult to avoid. Finally, the Broch case in 1960 indicated that little attention would be given arguments that attempt to justify a statutory interpretation on the basis of its economic desirability. 155

150 Rowe, supra note 89, at 133 n.40; Fisher, supra note 11, at 456-57; FeLDMAN \& ZoRN, op. cit. supra note 11, at 129-30; AusTIN, op. cit. supra note 77, at 120, 123 (by implication).

151 Guide 12. The courts also appear to regard this requirement as basic to a violation of 2(e). See, e.g., United Cigar-Whelan Stores Corp. v. H. Weinreich Co., 107 F. Supp. 89, 91 (S.D.N.Y. 1952) (dicta).

If "competing" were not read into section 2(e), such a result would broaden FTC authority to strike at territorial discrimination in the furnishing of services and facilities just as it can do in territorial price discrimination under section 2(a). One commentator regards this authority, assuming the prima facie 2(a) requirements, as necessary to protect the purposes of the Robinson-Patman Act. Austin, supra note 117, at 97.

152 Standard Oil Co. v. FTC, 340 U.S. 231 (1950). There is additional irony here, however, for the majority in Standard Oil was softening the thrust of a basically anti-competition act, while the literal reading of section 2(b) as it applied to 2(d) would have the opposite result.

153 Id. at 251 (Reed, J., dissenting).

154 FTC v. Simplicity Pattern Co., 360 U.S. 55, 67 (1959).

155 FTC v. Henry Broch \& Co., 363 U.S. 166, 177 (1960). Broch also showed that at the least a majority of the court might hesitate to overturn a "settled administrative practice." Ibid. If Commission interpretation had been less confused as to the question under discus- 
This result, of course, does not mean that a rigid application of section 2(d) vill stifle the flexibility of promotional allowances. As shown by the Atalanta ase, allowances on the first sale of a product can be adjusted on subsequent ales as long as the latter transactions are not in competition with the ormer. ${ }^{156}$ If the omission of payments for services from the 2 (b) defense was eally inadvertent, it should be left to Congress to change the words, and not he courts. Thus, there appears to be a valid distinction between adding a word smitted and altering unambiguous language.

\section{Conclusion}

It is evident that there is much in section 2 (d) to give rise to legal dispute. Some accommodation between the underlying intention of the section and the practical requirements of the business world may be seen in the Atalanta and Liggett \& Myers cases, and to some extent in the Guides. That this accommodation, however, will ever be a happy one is open to serious doubt. A study of Commission activity under the act from May through July, 1961, indizates that the charges under the advertising allowance section are three to four times more frequent than those brought under other sections. 157 Whether this indicates heretofore unnoticed violations in the business community or novel experimentation in new procedures and theories by the Commission is not altogether clear. Whatever the reason, it is manifest that important litigation testing the outer limits and internal workings of the section will be forthcoming.

sion, this additional reason could be given for predicting the Supreme Court's probable resolution of the problem.

136 The circuit court felt that the FTC construction of the "spot" sales five months apart as "competing" would mean "any allowance given on the first sale could never be adjusted to meet competition." Atalanta Trading Corp. v. FTC, 258 F.2d 365, 371 (3d Cir. 1958). (Emphasis added.) The quoted statement does not mean that the court was reading into 2(d) the defense of meeting competition.

${ }^{157}$ See FTC News Releases, May 1, 1961-July 31, 1961. 